\title{
Implementation of Interest in Buying Mikroskil Economic Students on Traveloka Online
}

\author{
Sarmauli Hanny Siagian ${ }^{1}$, M. Umar Maya Putra ${ }^{2}$, Meri Yanti ${ }^{1}$ \\ $\{$ umar_yazli@yahoo.com² $\}$ \\ ${ }^{1,3}$ STIE Mikroskil, Indonesia \\ ${ }^{2}$ Universitas Al Azhar, Indonesia
}

\begin{abstract}
This study aims to analyze the effect of buying interest on Traveloka online in Mikroskil Economic Students as the population. This type of research is descriptively quantitative. The sampling technique uses a purposive sampling method with a total sample of 43 respondents. Data collection techniques using a questionnaire that has been tested for validity and reliability. The data analysis technique used to answer hypotheses is multiple linear regression analysis. As the research result, advertising has no significant effect on buying interest and others give good ones. The coefficient of determination obtained was 0.561 that means it gives strong research for its buying behavior.
\end{abstract}

Keywords: interest, buying, Mikroskil, Traveloka.

\section{Introduction}

The development of the aviation industry is currently soaring high. It is indicated by the increasing number of airline promotions that have sprung up on domestic and international flights. The emergence of various airlines on various routes to make it easier for consumers to reach as well as varied promos make added value for consumers to make purchases in this innovative business. The airline concept of regions can be used as an early stage to start a business or industry was the inspiration for starting a business more innovative and strengthen the brand image of a business. With its inspiration, It can do the process of the existing products, which will create a diversified product and has a high business value when competing on market mechanisms [1].

The phenomena among students about airline progress with the dynamic and flexible with existing changes. They will look for their tickets to return to their hometowns, and some are looking for hotel tickets to go on vacation. There is a great diversity of students as social creatures who are always curious about technological advancements such as the use of Traveloka. By thinking of creating new creations in Traveloka, it gives the amazing condition. From its spirit will rise to become a big business online that has a high creation power in creating opportunities and support the customer's demand [2].

Advertising is one of the marketing forms about a product or service that is usually used to influence them so that it ends up in purchasing and has an impact on revenue for companies that use advertising as a form of marketing a product or service. One type of advertising that is often used in promoting goods or services is television advertising. It can make a good mentality and give good business advertising. Needs the research and development in 
empowering them to make better results in getting the best technology approvement for giving the easiest form [3].

Price is also a determinant that can affect the level of sales. It can increase the level of profit if the price has been given to a product or service is proportional to the quality of the product or service that can be obtained then the progress consumer's buying. It can guide consumers to get purchasing power. At present, the dominant market is available for the services for the affordable prices for all groups, especially the lower middle class. The presence of creativity and innovation can increase them to get an interest in developing a business and make the progress the business online. In the dynamics of its development, the business will be faced with limitations that need to be systematically resolved in adapting the price demand [4].

The service quality must also be considered in serving consumers, so they can get good responses from consumers. It is the advantage that can facilitate consumers in matters such as speed, accuracy, friendliness and service comfort. Quality of service has always been an interesting thing for many consumers. Customers are central to all marketing activities all over the world. Success for making them comfortable is not unthinkable and must be adapted to the market needs. Moreover, companies invest millions of dollars to attract them and make them loyal by their service excellence [5]. Buying interest is a person's interest to purchase an appropriate product or service. It is important to note because if there is a transaction on the purchase, Its sales will increase and the company's income increases. It will not get benefit from the product or service by using the internet for a comfortable moment.

The Internet is the beginning of the birth of the common marketing industrial era that causes an important connector in giving the buying power. It is utilizing the internet network to develop the strategies and result in ineffectiveness [6]. If there is no innovation and creativity in making the advancement of the industry, it can not be used as an early stage to start a business or industry. It was the inspiration for starting a business more creatively in the brand endorse [7]. Problems commonly faced by marketers in Indonesia is the level of productivity in producing a product. The quality of them that affects the business income less than the real target. They must improve the quality and support of research and development [8]. By developing the mindset to brand image is given the way of cracker that accentuated the culture of area wisdom centered on the market mechanism. The focus in productivity that can be very valuable for taking precedence [9].

It is necessary to make feasibility measurement for making the market need which is the main point in improving the quality of marketing is required marketer education support to be able to increase innovation in digital marketing online in airplanes [10]. By accelerating the company's ability, it is necessary not only to generate profits but also needs to be done the price control. It is certainly related to the activities of the community around the market in the airplane about the scheduled supply [11].

The buying customer needs today is relevant to the parties) in the determination of policies and strategies for future development. The way to be among their idea of how to accommodate them into good advertising through online business [12]. Based on the research phenomena, the researchers try to find out how Advertising, Price and Service Quality towards consumers' buying interest through Traveloka partially and simultaneously. 


\section{Materials and method}

This type of research used is a descriptively quantitative method. The object of the research is EconomicMikroskil student whose address is at Jalan Thamrin No. 112 in Sumatera Utara. The sampling technique used a nonprobability sampling design with a whole sampling one. Based on the size of the sample calculation obtained the number of samples in this study as many as 43 students. Data collection methods used in this study are both primary data and secondary data. The primary one obtained directly from respondents through the distribution of questionnaires and observations. Secondary one obtained from literature studies such as the study of theories relating to the variable Advertising, Prices, Service Quality and Buying Interest. Besides, articles in journals are related to previous research reviews.

Based on the variable, the Advertisingone includes advertising media, message creativity, and completeness of the information. The price variable includes affordability, competitiveness, price compatibility with product quality. The service quality one is an indicator of the service quality variables which include physical evidence (Tangible), Empathy, Responsiveness, Reliability, and Assurance. The variable Interest in buying is an indicator in the variable purchase interest includes transactional interest, referential interest, preferential interest, and exploratory interest. The data analysis method used is multiple linear regression. Data processing is performed using SPSS version 21 and is used to determine the results of descriptive statistics, test data quality, test classic assumptions, and test hypotheses. These variables can be written as follows

$$
\begin{gathered}
\text { Buying Interest }=a+b_{1} \text { Advertising }+b_{2} \text { Price }+b_{3} \text { Service Quality }+e \\
\qquad a=\text { Constanta } \\
b_{1}, b_{2}, b_{3}=\text { Coefficient Of Advertising, Price dan Service Quality }
\end{gathered}
$$

\section{Result and discussions}

The object research is PT. Trinusa Travelindo or better known as Traveloka. It is a company that provides online flight and hotel ticket booking services that focus on domestic travel in Indonesia. Traveloka has a headquarter based in Jakarta. The company was founded in 2012 by Ferry Unardi, Derianto Kusuma, and Albert. This idea arose when Ferry Unardi often experienced in ordering aircraft, especially when he wanted to return to Padang, Indonesia, from the United States. The initial concept of Traveloka functions as a search engine or Search Engine to compare flight ticket prices from various existing sites. In mid2013, It changed its initial site to a site for flight ticket reservations where users can make official and safe bookings. For the Item test in Table 1, it can be concluded that there is no problems occur so that it can be continued into other tests.

Table 1. Items for all the test

\begin{tabular}{cc}
\hline Items & Result \\
\hline Normality Test & Normal \\
Multikolieanity Test & No \\
Heteroskedasticity Test & No \\
Validity Test & Valid \\
Reality Test & Reliable \\
\hline
\end{tabular}


Multiple Regression analysis was made to analyze the value of Advertising, Prices, Service Quality that is called independent variables that it can result:

$$
\text { Buying Interest }=0,268+0,111 \text { Advertising }+0,339 \text { Price }+0,462 \text { Service Quality }+e
$$

The results of the SPSS Version 21 on these equations can be informed such as Constants (a) $=0,268$, it means that the independent ones are considered zero, the buying of the students is 0,268 unit. The high result in the advertising of 1 unit will increase the buying interest by 0.111 unit. For the price result of 1 unit will increase the buying interest by 0,339 unit. The service quality result of 1 unit will increase the buying interest by 0,462 unit The whole one can be seen in Table 2 .

Table 2. Multiple linear regression result, $t$ test, $F$ test and $\mathrm{R}^{2}$

\begin{tabular}{cccc}
\hline Model & Result & Significant & T-test \\
\hline Constant & 0,268 & 0,600 & 0,528 \\
Advertising & 0,111 & 0,520 & 0,649 \\
Price & 0,339 & 0,021 & 2,403 \\
Service Quality & 0,462 & 0,001 & 3,460 \\
F Test & 18,918 & $0,000^{\mathrm{b}}$ & \\
Adjusted R Square & 0,561 & & \\
\hline
\end{tabular}

The partial test (t-test) informs us to see the effect of independent factors as partially on buying interest. From the results of Table 2 with SPSS 21, both price and service quality obtained significant partially, however, advertising give the insignificant one partially with the decision significant criteria is accepted if $0<0.05$ at $\alpha=5 \%$. A simultaneous test (F Test) is used to find out whether there is a joint independent one. The following presented the results of the F test using SPSS 21 in Table 2is resulted F-table value can be seen 0 is lower than 0.05 at $\alpha=5 \%$. Among factors influence significantly in the buying interest simultaneously.

The determination coefficient $\left(\mathrm{R}^{2}\right)$ is used to know the independent ones to explain the dependent ones in Tabel 2. It is mentioned by the value of the adjusted $\mathrm{R}$ square is 0.561 . This means that $56.1 \%$ of the buying interest is explained by independent factors while the remaining $43.9 \%$ is mentioned by other variables. From the results of research, Traveloka seeks to provide the best advertising for an early stage to start a business or industry. From its spirit will rise to become an online creation of power opportunities. It can make a good mentality and give good business advertising. The presence of creativity and innovation can increase it to get an interest in developing a business. However, the respondents had already known the quality of Traveloka in terms of ticket and hotel purchases and hope to get high expectation creativity so that the advertisement provided by Traveloka does not affect them directly so that it doesn't fit to idea of [1], [2],[3] and [4].

The price given by Traveloka can affect students because it uses ongoing promotions so that the price given can be reached by students. They are central to all marketing activities. Internet is the beginning of its common marketing industrial era to affect them. The quality affects the business in the real target It was the inspiration for starting a business more creatively advantages on their payments such as being able to activate a pay later whose function can be paid by installments 12 times in use, so students will not feel heavy in terms of purchasing tickets or hotels through Traveloka.

The effect of service quality variables on consumer buying interest is because the students who get the best service from Traveloka customer service, which can help students if they 
have problems with purchases or want to make payments on tickets mindset to brand images via telephone. The feasibility measurements for making the market need and the services provided by Traveloka are very friendly so that students feel comfortable and safe can make students community trust in using Traveloka as the buying interest.

\section{Conclusions}

There are some conclusions that, advertising gives an insignificant result because of the high expectations by the students about creativity. The price is reasonably significant for them because it makes them focus the pay later service that makes them comfortable in brand image. The service quality is significant to make the flexible buying interest as the marketing program in making the best breakthrough. For the suggestion, it can be given to Traveloka that has already provided quality services, but it should add a live chat on the website or application so that consumers can contact the company quickly when faced with obstacles in purchasing tickets or hotels through available alternatives.

\section{References}

[1] A. Dilham., Putra, M. Umar Maya. "Business Motivation Strategy In Tandem Hilir District 1 Five 1," In The 1st Multi-Disciplinary International Conference University Of Asahan2019 Thema: The Role Of Science In Development In The Era Of Industrial Revolution 4.0 Based On Local Wisdom." In Sabty Garden Hotel-Kisaran North Sumatra, March 23rd, 2019, 2019, pp. 374-379.

[2] Syarifah, Tengku., Putra, M. Umar Maya. "Motivation And Entrepreneurs Training For Tinggi Raja Society Of Asahan Regency,” Vol. 104, No. Aisteel, pp. 1-5, 2017.

[3] Putra, M. Umar Maya., Bati, Putra, And H. Sahla. "Focus Group Discussion For Young Entrepreneurs Training In University Of Asahan,” Vol. 200, pp. 1-4, 2018.

[4] Saleh, Malawat., Putra, M. Umar Maya. "Business Start-Up Empowerment In Asahan District 1," In The 1st Multi-Disciplinary International Conference University Of Asahan2019 Thema: The Role Of Science In Development In The Era Of Industrial Revolution 4.0 Based On Local Wisdom." In Sabty Garden Hotel-Kisaran North Sumatra, March 23rd, 2019 Business, 2019, pp. 299-304.

[5] A. Dilham., F. R. Sofiyah., I. Muda., U. S. Utara. "The Internet Marketing Effect On The Customer Loyalty Level With Brand," Vol. 9, No. 9, pp. 681-695, 2018.

[6] I. M. Dilham., Ami, Five Rahmatus Sofiyah. "The Internet Marketing Effect On The Customer Loyalty Level With Brand Awareness As Intervening Variables," Int. J. Civ. Eng. Technol., Vol. 2, No. December, pp. 681-695, 2017.

[7] S. Malawat., Putra, M. Umar Maya. "Socio-Economic Kisaran Barat Community Mapping In Asahan Regency," pp. 706-713, 2018.

[8] Ami, Dilham., Putra, M. Umar Maya. "Socio-Economic Community Mapping Around Dumai Timur (Case Study: Tanjung Palas Village)," In IOP Conf. Series: Earth And Environmental Science 126 (2018) 012085, 2017, pp. 1-10.

[9] Dian, Wahyuni., Putra, M. Umar Maya. "Entrepreneurship And Business Ethics In Civil Society of Tinggi Raja District Asahan Regency," In The Implementation of Language, Literature, Art And Cultural Studies In Strengthening The Nation 'S Civilization, 2017, pp. 255-259.

[10] M. S. Malawat., Putra, M. Umar Maya. "Review Of Implementation In Bunut Shoes Assistance Program In Order Of Micro, Small And Medium Enterprises Economic In Asahan Regency," in Journal of Physics: Conference Series, 2018, vol. 970, no. 1, pp. 1-6.

[11] Putra, M. Umar Maya., Ami. "An Effectiveness Analysis of Corporate Social Responsibility of Empowerment Program in Terminal BBM Pertamina Siantar," 2017, no. 1987, pp. 457-463. 
[12] A. Dilham., Putra, M. Umar Maya. "Social-Economic Community Mapping Around Binjai Utara ( Case Study: The People In Tandem Hilir )," in Proceedings of the 1st Annual International Seminar on Transformative Education and Educational Leadership (AISTEEL) eISSN: 2548-4613, 2016, no. ii, pp. 600-607. 